\title{
Effect of organic and syntetic fertilizers on soil productivity in organic tomatoes production
}

\author{
Funda ULUSU*, Elif YAVUZASLANOĞLU \\ Karamanoğlu Mehmetbey University Technical Sciences Vocational School, Plant and animal Production \\ Department, Karaman \\ *fulusu@kmu.edu.tr
}

\section{Organik ve sentetik gübrelerin organik domates yetiştiriciliğinde toprak verimliliğine etkisi}

\begin{abstract}
Organic fertilizer is a plant nutrient material which is used for obtaining the requirements of nutrients of plants grown in agricultural production. Organic fertilizers increase the organic matter content by providing nutrients to the soil as well as providing a more favourable growth environment for plants by correcting the physical properties of the soil. Organic fertilizers, mainly nitrogen, phosphorus, potassium, such as many important nutrients are brought to the soil. Chemical fertilizers can be obtained from petroleum products, from rocks and even from organic sources. This type of fertilizer helps plants grow, but there is no contribution to the development of the soil. In this study, each of the pots was applied in $500 \mathrm{ml}$ of water at the stage of seedling uptake and 3 times in 3 weeks intervals following the application of the organic, synthetic fertilizer at a dosage of $200 \mathrm{cc} / \mathrm{da}$. The experiment was set up in pots with 5 replicates and was grown under greenhouse conditions. At the end of the experiment some physicochemical properties such as $\mathrm{pH}$, salt, lime, phosphorus, potassium, iron and copper contents of the pots were investigated. The effect of these fertilizers on soil productivity has been evaluated. Phosphorus, potassium and iron contents in fertilizer applications were recorded as high compared to the negative control. In addition, the lowest soil $\mathrm{pH}$ was obtained in the application of synthetic fertilizer. This study has shown that organic fertilizer is more useful than synthetic fertilizer in terms of soil productivity.
\end{abstract}

Key words: tomatoes, fertilizer, soil productivity

Özet: Organik gübreler yetiştirilen bitkilerin bitki besin maddesi ihtiyaçlarını sağlamaları amacıyla kullanılan bitki besleme materyalidir. Organik gübreler yüksek organik madde içermesinden dolayı hem topraklara besin maddesi sağlayarak organik madde muhtevasını arttırır hem de toprakların fiziksel özelliklerini düzeltir. Organik gübrelerle, başta azot olmak üzere, fosfor, potasyum, gibi önemli birçok besin elementleri toprağa kazandırılır. Kimyasal gübreler; inorganik, petrol ürünlerinden, kayaçlardan ve hatta organik kaynaklardan elde edilebilirler. Bitkilerin gelişmesine yardımcı olurlar ancak toprağın gelişmesi için hiçbir katkıları yoktur. Bu çalışmada melas kökenli organik ve sentetik gübre $200 \mathrm{cc} /$ da dozajında her bir saksıya $500 \mathrm{ml}$ su içerisinde fide şaşırtma aşamasında ve takibinde 3 er hafta aralıkla $3 \mathrm{kez}$ uygulanmıştır. Deneme saksılarda 5 tekerrürlü olarak tesadüf parselleri deneme desenine göre kurulmuş ve sera koşullarında yetiştirilmiştir. Denemenin sonunda saksılardaki toprakların $\mathrm{pH}$, tuz, kireç, fosfor, potasyum, demir ve bakır içeriği gibi bazı fizikokimyasal özellikleri incelenmiştir. Bu gübrelerin toprak verimliliğine etkisi değerlendirilmiştir. Gübre uygulamalarında ki fosfor, potasyum ve demir içerikleri negatif kontrole göre yüksek olarak kayıt edilmiştir. Buna ek olarak, en düşük toprak pH'ı sentetik gübre uygulamasında elde edilmiştir. $\mathrm{Bu}$ çalışma ile toprağın verimliliği açısından organik gübrenin sentetik gübreye göre daha faydalı olduğu gösterilmiştir.

Anahtar Kelimeler: domates, gübre, toprak verimliliği

\section{Introduction}

Tomatoes are one of the vegetables produced in temperate climate zone in the world. Origin of tomatoes is Peru, it is started to be produced in Anatolia in 1900s. Production is more intense in Trace, Aegean, and Mediterranean Regions (Kandemir et. al., 2017). Deep, well aerated, rich in organic matter soils, $\mathrm{pH}$ at 6,5 and EC lower than 2,3 $\mathrm{mS}$ are appropriate for tomatoes production (Lewandowski and Zumwinkle, 1999). Addition of organic matter into soil develops the physical properties and provides sustainability (Bender et. al., 1998).

Sustainability of soil fertility is essential for sustainability of plant production. Sustainable plant production is to obtain enough qualified product without exhaust the natural sources and destroy the nature. It needs to be balanced the plant nutrition objects in soil in addition to climatic factors for sustainability of soil fertility. For this purpose; rotation of plant production and controlled soil tilling is suggested. Organic matter content of most of the soils in Turkey is lower (less than 2\%) (Karaman et al., 2007; Zengin, 2017).
Therefore; soil fertilizing, using farm fertilizer or synthetic fertilizers, is very important component of plant production in Turkey.

Organic fertilizers are originated from plant and animal wastes, therefore is recycled in the soil. They contain N, P, $\mathrm{K}$ and microelements in different rates depending to the source of the fertilizer. Organic fertilizers speed the microbial reactions and provides micro and macro elements for plant production, beside develops the stricture and aerated the soil.

In contrast, inorganic fertilizers are produced by decomposition of petrol derivatives, rocks and organic matters and contain directly micro and macro elements in. Those are useful for plant development but are not for soil fertility (Yetgin, 2010).

Six million tones inorganic fertilizer, 39 million tones synthetic agricultural additional chemicals and hormones are used in Turkey (Yetgin, 2010). Unconscious use of the chemicals in agricultural practices, natural balance is broken down and as a result, it makes treat to livings through the food chain. Due to the negative effects of the 
inorganic fertilizers, use of the organic fertilizers is encouraged. In this study, the effect of organic and synthetic fertilizers used in tomatoes production on soil fertility was investigated.

\section{Materials and Method}

Organic tomatoes seeds of "Kokteyl" variety were used from Ekoherb firm. Experiment was set up in $20 \mathrm{~cm}$ diameter plastic pots and placed into greenhouse during March-September 2015. The soil used in the pots contained $25,9 \%$ calcium and $1,11 \%$ organic matter, $\mathrm{pH}$ was 7,8 and EC(Electric Conductivity): $0,01 \%$. Organic fertilizer originated from molasses containing $7 \% \mathrm{~N}, 7 \% \mathrm{P}$ and $7 \% \mathrm{~K}$ and synthetic fertilizer(NPK fertilizer solution) containing $10 \% \mathrm{~N}, 8 \% \mathrm{P}$ and $5 \% \mathrm{~K}$ at dosage of $200 \mathrm{cc} /$ da were applied in $500 \mathrm{ml}$ tap water at seedling transfer and 3 times more with 3 weeks intervals. Negative check without any fertilizer application was included. Experiment was designed according to randomized plot design with five replications. Fruits and plants were harvested after four months later at the end of the experiment and soil in each pot was analyzed for soil productuvitiy. pH (Richards, 1954), EC (Richards, 1954), P (Knudsen, 1975), K (Carson, 1980), Fe, Cu, organic matter (Walkley, 1946) and $\mathrm{CaCO}_{3}$ (Çağlar, 1949) were analyzed for soil fertility. Statistical differences for soil fertility among fertilizer treatments were compared using ANOVA analysis.

\section{Results}

Statistically important differences among fertilizer applications were obtained for $\mathrm{pH}, \mathrm{EC}, \mathrm{P}, \mathrm{K}, \mathrm{Fe}$ and $\mathrm{Cu}$ content. There was not any statistical difference for $\mathrm{CaCO}_{3}$ and organic matter among the treatments.

The measurement of the soil salt; EC was higher in both fertilizer treatments being maximum in organic fertilizer treatment than negative check treatment. However there was not any statistical difference between fertilizer applications (Figure 1).

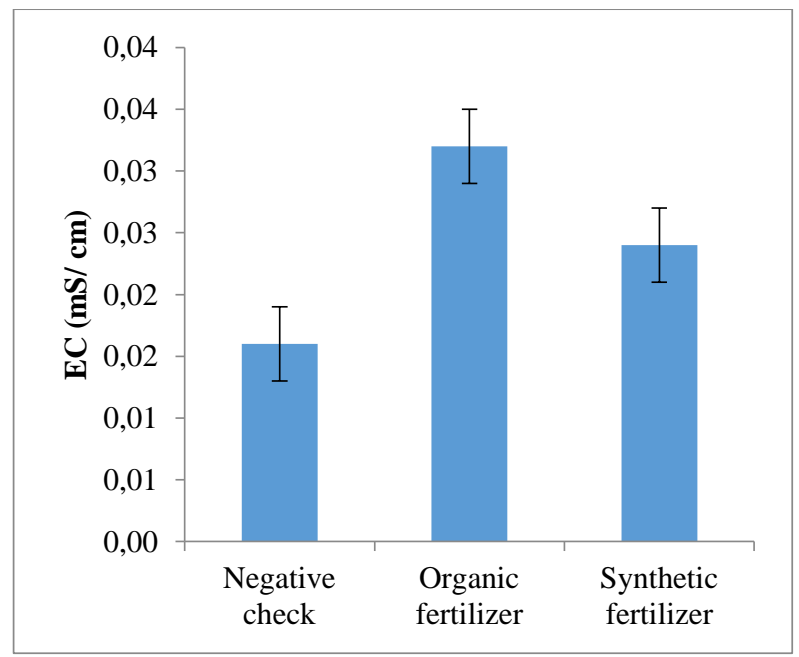

Figure 1. Soil EC $(\mathrm{mS} / \mathrm{cm})$ in fertilizer treatments in the experiment.

Soil $\mathrm{pH}$ was statistically importantly lower in synthetic fertilizer treatment being highest in organic fertilizer treatment (Figure 2).

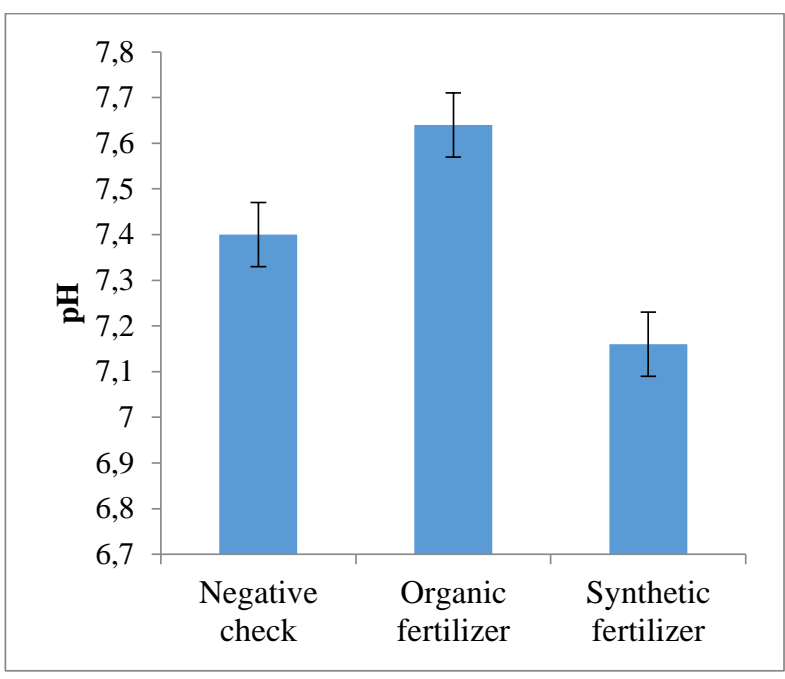

Figure 2. Soil $\mathrm{pH}$ in fertilizer treatments in the experiment.

Soil $\mathrm{P}, \mathrm{K}$ and $\mathrm{Fe}$ contents in both fertilizer treatments were higher than negative check (Figure 3, 4 and 5).

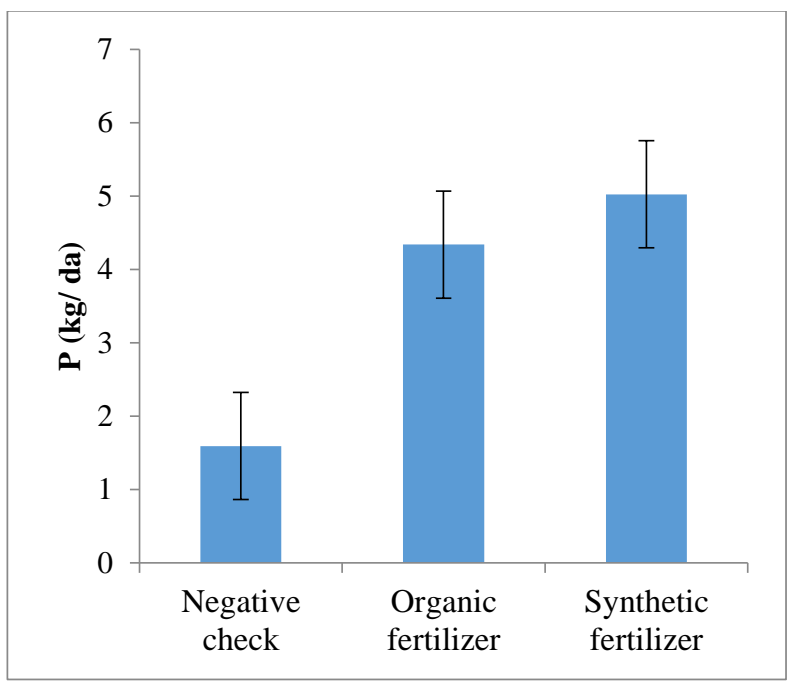

Figure 3. The soil $\mathrm{P}(\mathrm{kg} / \mathrm{da})$ in fertilizer treatments in the experiment.

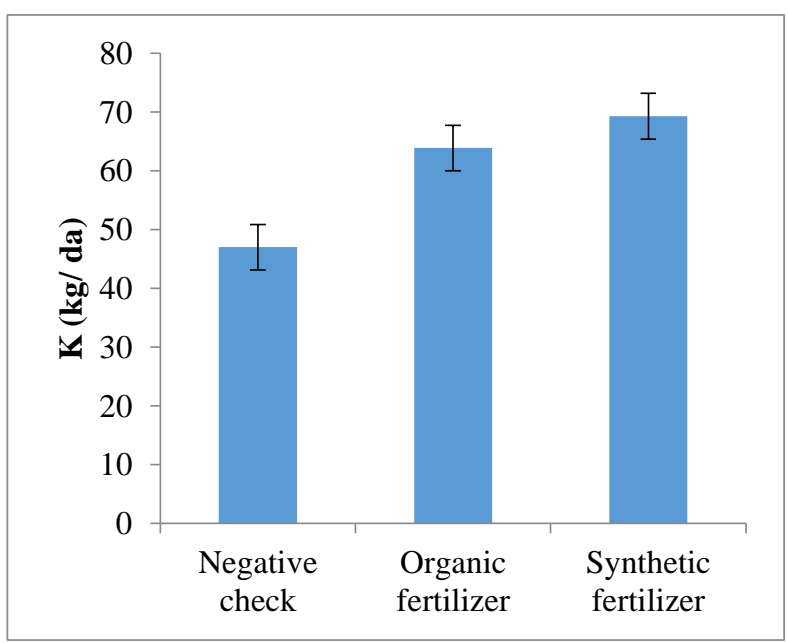

Figure 4. The soil $\mathrm{K}(\mathrm{kg} / \mathrm{da})$ in fertilizer treatments in the experiment. 


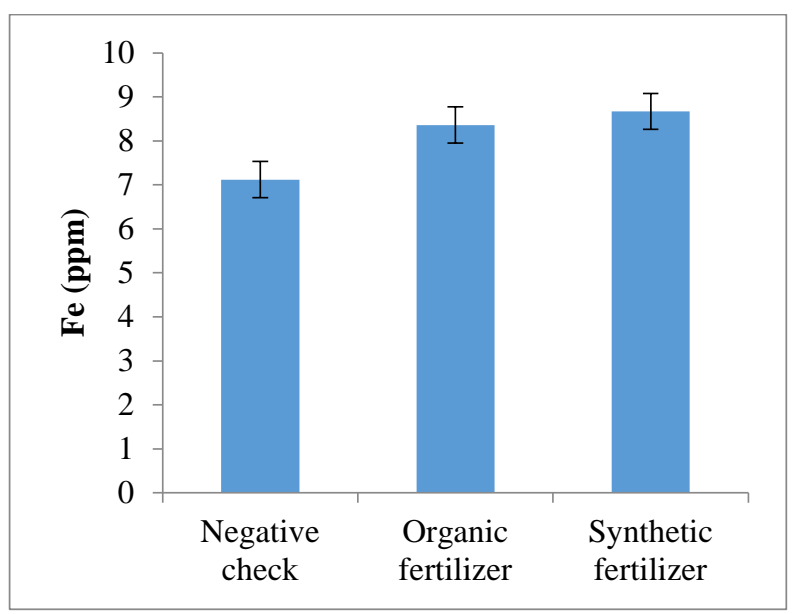

Figure 5. The soil $\mathrm{Fe}(\mathrm{ppm})$ in fertilizer treatments in the experiment.

Soil content of $\mathrm{Cu}$ was lower in syntetic fertilizer treatment, being the highest in organic matter treatment (Figure 6).

\section{Discussions}

Tomatoes are produced under greenhouse conditions prevalently in Turkey. Therefore the same land is used continuously for same product causing consumption of macro and micro elements. Soil fertilizing and application of soil regulating materials are frequently applied to avoid from soil exhausting. Synthetic fertilizers are effective only for one growing season, they are moved with underground water in the next year (Yetgin, A. M., 2010). Despite, organic fertilizers are slowly solved in soil water and useful for long time for the plant. Use of organic fertilizers is important for sustainability of soil fertility. Higher salt accumulation with higher EC value in both fertilizer treatments were due to the mineral content of the fertilizers. This is the result of soil fertilizing reported previously in agricultural soils (Ekmekçi et. al., 2005).

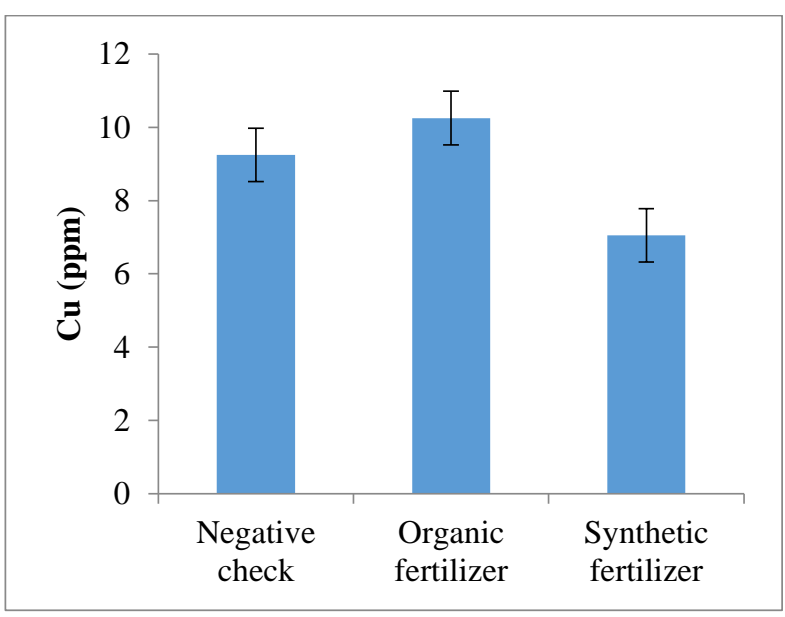

Figure 6. The soil $\mathrm{Cu}(\mathrm{ppm})$ in fertilizer treatments in the experiment.

The best medium for soil microorganism activity is slight alkali soil reaction (Bender et. al., 1998; Lewandowski and Zumwinkle, 1999). Beside, synthetic fertilizer gives the minerals to the soil ready for the plants and does not have any effect on soil microbial activity. Moreover, causes inappropriate conditions reducing the soil $\mathrm{pH}$ level. In the experiment, soil medium was highly acidic in synthetic fertilizer treatments. Therefore, reducing effect on soil microbial activity is shown obviously. Macro and micro elements for plant nutrition were provided succesfully in the soil from organic fertilizer as well as synthetic fertilizer in the experiment.

As a result, organic fertilizer increased soil mineral and organic matter content and developed the soil reaction for microorganism activity. Therefore organic fertilizers originated from molasses are good alternatives to synthetic fertilizers for tomato production under greenhouse conditions.

\section{References}

Bender D, Erdal İ, Dengiz O, Gürbüz M, Tarakçıŏlu C (1998). Farklı Organik Materyallerin Killi Bir Toprağın Bazı Fiziksel Özellikleri Üzerine Etkileri. International Symposium On Arid Region Soil. International Agrohydrology Research And Training Center, Menemen, İzmir.

Çağlar KÖ (1949).Toprak Bilgisi. Ankara Üniversitesi Ziraat Fakültesi Yayınları, Ankara.

Carson PL (1980). Recommended potasium test. In: Recommended Chemicalsoil test procedures for the North Central Region. Rev.ed., North Central Regional Publication no.221. North Dakota Agric. Exp. Stn. North Dakota StateUniversity, Fargo. USA.

Ekmekçi E, Apan M, Kara T (2005). Tuzluluğun Bitki Gelişimine Etkisi. Ondokuzmayıs University Journal of Faculty of Agriculture 20(3):118-125.

Kandemir D, Kurtar S E, Demirsoy M (2017). Türkiye Örtüaltı Domates Yetiştiriciliğindeki Gelişmeler. Turktob 17:22-27.

Karaman MR, Brohi AR, Müftüoğlu NM, Öztaş T, Zengin M (2007). Sürdürülebilir Toprak Verimliliği. Detay Yayınlharı, Ankara.

Knudsen A (1975). Recommended phosphorus soil tests. In: Recommend chemical soil test procedure. North Central Regional Publication no: 221, Wisconsin

Lewandowski A, Zumwinkle M (1999). Assessing the Soil System. A Review of Soil Quality Literature. Minessota Department of Agriculture Energy and Sustainable Agriculture Program, Boulevard.

Richards LA (1954). Diagnosis and Improvement of Saline and Alkaline Soils. U.S. Dep. Agr. Handbook, Washington.

Walkley A (1946). A Critical Examination of a Rapid Method For Determining Organic Carbon in Soils-Effect of variations in digestion conditions and of inorganic constituents. Soil Scence 63: 251-263. 
Yetgin MA (2010). Organik Gübreler ve Önemi. İl Tarım Müdürlüğü, Çiftçi Eğitimi ve Yayın Şubesi Yayını, Samsun.

Zengin, M., (2017). Tarımda Toprak Verimliliği Nasıl Artırılır, http://www.kutahyaazot.com/kataloglar/Toprak_Verimliligi_ (Mehmet\%20ZENG\%C4\%B0N).pdf (Erişim tarihi: 26.10.2017).

Cite this article: Ulusu F, Yavuzaslanoğlu E (2017). Effect of organic and syntetic fertilizers on soil productivity in organic tomatoes production. Anatolian Journal of Botany 1(2): 45-48. 